\title{
Use of Sorghum for Enhancing the Biodiversity and Nutritional Value of Semi-Desert Pasture Ecosystems
}

\author{
G K Bulakhtina', A V Kudryashov' ${ }^{1}$ N I Kudryashova1, A B Volodin², \\ M M Shagaipov ${ }^{3}$, M Sh Gazieva ${ }^{3}$, and A II Ferzauli ${ }^{3}$ \\ ${ }^{1}$ Department of Environmental Management, Caspian Agrarian Federal Research Center, Russian \\ Academy of Sciences, Astrakhan region, Russia \\ 2Sorghum laboratory, North Caucasus Federal Scientific Agrarian Center, Stavropol region, \\ Russia 3Grozny State Petroleum Technical University n.a. academician M.D. Millionshchikov, \\ Grozny, Russia
}

\section{Abstract}

The article presents the results of studies on the adaptive potential of sorghum used for restoration of degraded pasture ecosystems, increasing their biodiversity and nutritional value. The region chosen for the experiment is a semi-desert arid part of southern Russia. The aridity coefficient is $0.11-0.30$ which is typical of the arid zone. The annual volume of precipitation is $125-265 \mathrm{~mm}$. Two varieties of sorghum -- Travinka and Caravan -- were studied. They were grown with different thickness: 10 thousand, 20 thousand and 40 thousand plants per 1 hectare. During the growing season, there was soil and atmospheric drought. The best indicators of green mass yield were recorded for Travinka for the variant " 40 thousand plants per hectare -- 7.9 tons per hectare, and for Caravan for the variant "20 thousand plants per hecrate -3.9 tons per hectare. Compared with natural pasture, sorghum productivity is 18 times higher by green mass yield and 26 times higher by dry mass yield (the best options). The analysis of the chemical composition and nutritional value of sorghum showed that compared to the plants of natural pasture, sorghum is a more nutritious fodder plant. Its nutritional value is more by 0.24 feed units per $1 \mathrm{~kg}$ and by $1.9 \%$ by the mass of crude protein. It is better than other plants by the content of sugar content $(79 \mathrm{~g}$ per $1 \mathrm{~kg}$ ) and macronutrients.

Keywords: perennial, sorghum, arid pastures, biodiversity, nutritional value

\section{Introduction}

The natural ecological system is an objectively existing part of the natural environment which has spatial territorial boundaries within which living (plants, animals and other organisms) and non-living elements interact as a single functional entity and are interconnected by the exchange of substance and energy: the elements form a stable 
integral system (ecological balance). Violation of the ecological balance causes adverse environmental effects.

Pasture ecosystems are ecosystems with altered trophic fluxes of biomass and energy, and circulation of substances due to the grazing effects on vegetation, soil and fauna. Therefore, even with a completely rational use of pastures, constant monitoring of the ecosystem is required.

Semi-desert and desert pastures are areas of beef, fine-wool and astrakhan sheep, horse and camel breeding. Due to extreme soil and climatic conditions and increasing pasture degradation, the nutritional value of the vegetation cover is low. There is not enough food for animals grazing on natural pastures. The nutritional value ranges from 10 to $41 \%$ depending on the region $[1,2]$.

Under the influence of anthropogenic and other factors, outcrop of the earth surface, violation of pasture areas, mobile sands can be observed. Under the influence of unregulated grazing, composition diveristy of grasses, shrubs and subshrubs decreased. Only over the last 30 years, Izen (Kochia), Tethyr (Salsola gemmascens Pall.), Camphorosma (Camphorosma), Teresken (Ceratoides), perennial grasses Zytnyak (Agropyron), sainfoin (Onobrychis), Astragalus (Astragalus) have almost disappeared. Disappearance of astragalus and sainfoin (Fabaceae) significantly reduces the amount of nitrogen; disappearance of izen, tetyr, camphoros (halophytes) salinizes the soil. Thus, violation of the species structure of semi-desert ecosystems reduces pasture biodiversity and affects the environment [3--5].

These problems are relevant throughout the world. Most pastures in New Mexico (USA) are degraded due to regular droughts and high grazing pressure [12].

The conceptual basis for combating land degradation is the balanced impact of natural and anthropogenic factors on the climate-soil-water-wildlife-plant system. The results of theoretical studies and accumulated practical experience indicate that the natural resource potential of degraded agricultural land can be improved by complex land melioration aimed at reducing natural salinity, alkalinity, and preventing secondary salinization. In addition to the main areas of land reclamation (hydrotechnical and chemical), a third one should be used -- phytomelioration. It is based on the use of the biological regenerative potential of plants which historically has been the main environmental factor of soil formation [6]. For example, due to the diversity of the mechanisms of tolerance (osmoregulation, presence of enzymatic and non-enzymatic antioxidants), halophytes have a large range of ecological and biological characteristics and possibilities for economic use. Therefore, halophytes are ideal for reclamation of saline lands $[7,8]$. 
To preserve plants disappearing from arid pastures, the following measures have to be taken: collection of seeds of disappearing plants, creation of nursery gardens, formation of the gene pool, selection of promising samples, development of agricultural techniques, etc. These measures contribute to preservation of the gene pool of endangered valuable species of pasture forage plants. Mobilization of plant resources in the arid zone and creation of their gene pool will help save rare endangered plant species; compare various species, ecotypes and forms by their economically valuable and ecological biological features which makes it possible to identify species and forms with a wide range of adaptive abilities allowing for restoration of degraded ecosystems of arid pastures. The identified promising species and samples can be used for introduction into culture as a promising starting material for selection and as phytomeliorants for arid zones [9].

The article aims to study agrobiological features of cultivation of sorghum in the soil and climatic conditions of the arid zone of southern Russia for restoration of degraded pasture ecosystems. The research task is to study economically valuable properties of sorghum.

\section{Methods and Materials}

Perennial sorghum was created by A.I. Derzhavin. The maternal plant was sugar sorghum (No. 110 in the State Register) was characterized by high drought resistance and high (up to 18-19\%) sugar content. The father plant is wild perennial sorghum (gumay). It was characterized by a powerful tillering force, thin well-leafed stems and high grain productivity. In 2004, two varieties were introduced into the State Register: Travinka and Caravan.

For the research purpose, we used a method suggested by the group of authors selected the varieties of sorghum (Pospelova, Pospelov, Komarov), the Unified Classifier of the CMEA and the International Classifier of the CMEA of the cultivated species of Sorghum moench" developed by the Research Institute of Crop Production n.a. Vavilov (1982) $[10,11]$.

The region chosen for the experiment is a semi-desert arid part of southern Russia. The aridity coefficient is $0.11-0.30$, which characterizes the strongly arid zone. The annual volume of precipitation is $125--265 \mathrm{~mm}$. The duration of the period with temperatures above $10{ }^{\circ} \mathrm{C}$ is $165--170$ days. The sum of effective temperatures for pasture grasses above $5{ }^{\circ} \mathrm{C}$ reaches $5800--5900{ }^{\circ} \mathrm{C}$. Evaporation is $3--5$ times higher than the amount of precipitation. The probability of dry and dry years exceeds $60 \%$. 
The study of perennial sorghum was carried out by two factors: different varieties -- Travinka and Caravan -- and standing density: 10 thousand, 20 thousand and 40 thousand plants per 1 ha.

The soils of the experimental plot are light brown, alkaline, heavy loamy in combination with solonets from 5 to $10 \%$.

The analysis identified the composition of the soil: the content of humus is very low (0.75\%); alkaline hydrolysable nitrogen -- very low (32 mg/kg); rolling phosphorus -high (49 mg/kg); potassium rolling -- from medium to high (408 mg/kg). By the end of the growing season, humus decreased by $0.12 \%$ and nitrogen decreased by $4 \mathrm{mg} / \mathrm{kg}$ (Table 1).

TABLE 1: Results of the agrochemical analysis of the soil for growing sorghum.

Indicators
Water pH
Organic substance (humus)
Alkaline Nitrogen
Mobile phosphorus
Mobile potassium

$\begin{gathered}\text { Unit of } \\ \text { measurement }\end{gathered}$
$\mathrm{pH}$ units
$\%$
$\mathrm{mg} / \mathrm{kg}$
$\mathrm{mg} / \mathrm{kg}$
$\mathrm{mg} / \mathrm{kg}$

\begin{tabular}{|c|c|}
\hline \multicolumn{2}{|c|}{ Analysis result } \\
$\begin{array}{c}\text { Before the vegetation } \\
\text { period }\end{array}$ & $\begin{array}{c}\text { After the vegetation } \\
\text { period }\end{array}$ \\
7.9 & 8.0 \\
\hline 0.75 & 0.63 \\
32 & 28 \\
\hline 49 & 61 \\
408 & 488 \\
\hline
\end{tabular}

The natural pasture with identical soil and climatic parameters was selected as a control pasture: water $\mathrm{pH}$-- 7.9; humus -- $0.76 \%$, alkaline hydrolysable nitrogen -- 33 $\mathrm{mg} / \mathrm{kg}$, mobile phosphorus -- $48 \mathrm{mg} / \mathrm{kg}$, mobile potassium -- $410 \mathrm{mg} / \mathrm{kg}$.

The vegetation cover of the natural pasture is a highly degraded wormwoodbluegrass combination with a depleted species composition: Artemisia terrae-albae Krasch., Artemisia lerchiana, Roa bulbosa L., lyme grassum Alyssum desertorum Stapf, Ceratocarpus arenarius L. The total cover is 15--25 \% (Fig. 1).

\section{Results}

Sorghum was sown on April 11th. The air temperature (average) was $+12{ }^{\circ} \mathrm{C}$, the soil at the depth of the seed set $(4--6 \mathrm{~cm})$ was $+14{ }^{\circ} \mathrm{C}$, the productive moisture reserve in the soil was $22 \mathrm{~mm}$.

Analysis of the meteorological conditions of the growing season showed that from April to July, there were extremely negative conditions for the growth and development 


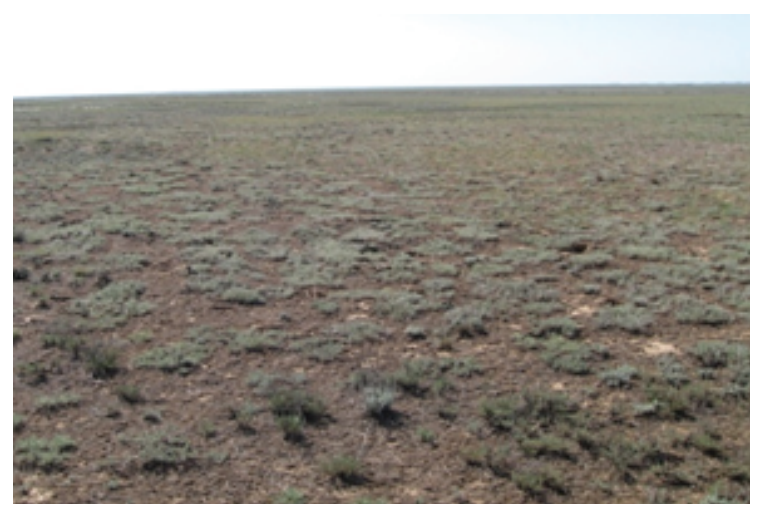

Figure 1: Semi-desert natural pasture (a control plot).

of sorghum: an increase in average air temperature by $1.1-3.7^{\circ} \mathrm{C}$ compared to the longterm averages, in the daytime the temperature reached $45--50^{\circ} \mathrm{C}$, there no precipitation in May and June. The presence of productive moisture in the soil during the growing season was studied (Fig. 2).

Figure 2 shows that during the summer period, there was no productive moisture in the soil at a depth of 0--0.3 m. By late autumn, it reached satisfactory indicators.

Thus, during the beginning and active growing season, soil and atmospheric drought was observed, since relative air humidity was below $30 \%$ and there was no productive moisture in the soil.

However, even in such extremely stressful conditions, all the vegetation phases were normal (Table 2).

TABLE 2: Dates of full sorghum vegetation phases.

\begin{tabular}{|c|c|c|c|c|c|c|} 
Sowing & Seedlings & Tillering & $\begin{array}{c}\text { Stem } \\
\text { elongation }\end{array}$ & $\begin{array}{c}\text { Ear } \\
\text { emergence }\end{array}$ & Blooming & Maturation \\
\hline 11.04 & 03.05 & 23.05 & 25.06 & 10.07 & 28.07 & 15.10 \\
\hline
\end{tabular}

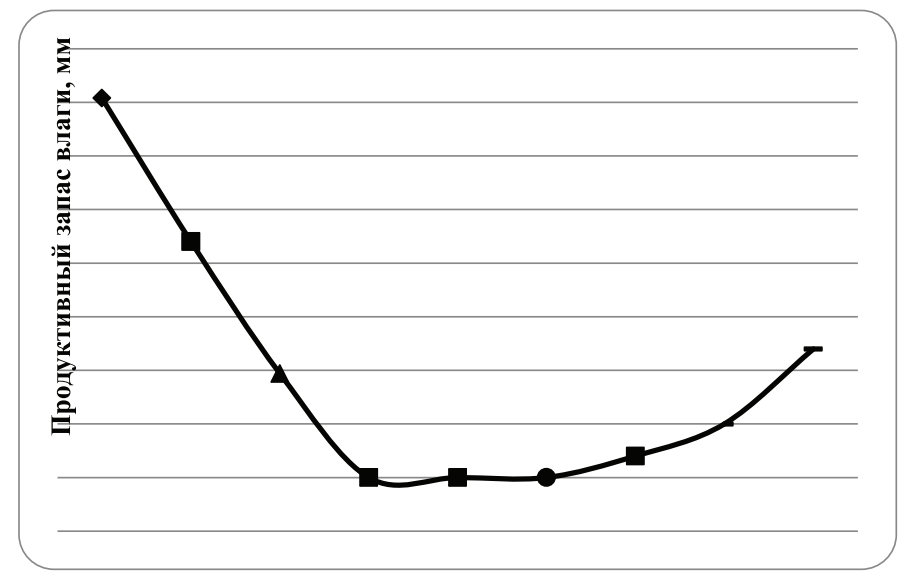

Figure 2: Changes in the productive reserve of moisture $(\mathrm{mm})$ in the soil at a depth of 0--0.3 $\mathrm{m}$ by months. 
When studying sorghum yields, it was found that the most productive variety was Travinka with a standing density of 40 thousand plants per hectare -- 7.9 tons per hectare. Caravan with a standing density of 20 thousand plants per hectare had a yield of 3.9 tons per hectare. In comparison with the natural pasture (green mass yield is 0.44 tons per hectares, dry mass yield is 0.15 tons per hectares), sorghum yield is 18 times higher by green and 26 times by dry mass (the best options) (Fig. 3, Table 3).

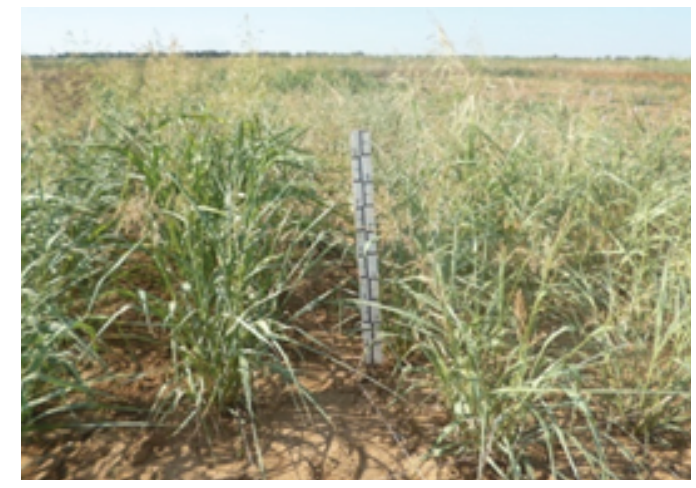

Figure 3: Perennial sorghum, Caravan, the ear emergence phase.

TABLE 3: Sorghum yield (tons per hectare) by varieties.

\begin{tabular}{l} 
Standing \\
density/ \\
Variety \\
\hline Caravan \\
Travinka
\end{tabular}

\begin{tabular}{c|c|}
\hline 10 thousand plants/ha \\
\hline $\begin{array}{c}\text { green mass } \\
\text { yield }\end{array}$ & $\begin{array}{c}\text { dry mass } \\
\text { yiled }\end{array}$ \\
\hline 1.2 & 0.6 \\
\hline 2.1 & 1.0 \\
\hline
\end{tabular}

\begin{tabular}{c|c|}
\hline 20 thousand plants / ha \\
$\begin{array}{c}\text { green mass } \\
\text { yield }\end{array}$ & $\begin{array}{c}\text { dry mass } \\
\text { yiled }\end{array}$ \\
\hline 3.9 & 1.9 \\
\hline 3.5 & 1.7 \\
\hline
\end{tabular}

40 thousand plants / ha

\begin{tabular}{|c|}
\hline $\begin{array}{c}\text { green mass } \\
\text { yield }\end{array}$ \\
\hline 3.4 \\
7.9 \\
\hline
\end{tabular}

dry mass yiled 1.7 3.9

The main indicators of the perennial sorghum analysis are as follows:

1. plant height -- 0.67--0.78 m;

2. weight of the aerial part of 1 plant -- 0.198--0.207 kg;

3. bushiness -- 10--13 units;

4. foliage -- 51--67 units;

5. average stem diameter -- 7--8 $\mathrm{mm}$;

6. average height of the stems -- $0.46 \mathrm{~m}$.

Analysis of the results of studies of the chemical composition and nutritional value of the dry mass of perennial sorghum showed the absence of a significant difference 
TABLE 4: Chemical composition and nutritional value of sorghum and natural grass per for a dry substance.

Indicators
Dry substance content
Mass fraction of raw ash
Mass fraction of crude protein
Mass fraction of crude fiber
Mass fraction of crude fat
Feed units

\begin{tabular}{|c|}
$\begin{array}{c}\text { Measurement } \\
\text { unit }\end{array}$ \\
\hline \\
\hline$\%$ \\
\hline$\%$ \\
\hline$\%$ \\
\hline$\%$ \\
\hline$\%$ \\
\hline F.u.
\end{tabular}

\begin{tabular}{|c|c|}
\hline \multicolumn{2}{|c|}{ Variety } \\
\hline Caravan & Travinka \\
\hline $92.3+1$ & $92.8+1$ \\
\hline 6.6 & 6.3 \\
\hline 9.1 & 9.4 \\
\hline $29.8+2.4$ & $30.3+2.4$ \\
\hline $2.41+0.5$ & $2.59+0.5$ \\
\hline 0.66 & 0.65 \\
\hline
\end{tabular}

\begin{tabular}{|c|}
\hline $\begin{array}{c}\text { Natural } \\
\text { pasture }\end{array}$ \\
\hline $94.2+1$ \\
\hline 6.1 \\
\hline 7.5 \\
\hline $18.6+2.4$ \\
\hline $2.40+0.5$ \\
\hline 0.42 \\
\hline
\end{tabular}

between varieties. However, compared to the grassland of natural pasture, sorghum is a more nutritious fodder plant (Table 4).

Using the data on the nutritional value of sorghum, the yield per one hectare was determined (Table 5).

TABLE 5: Yield of fodder units per 1 ha of perennial sorghum ( $t$ ) by varieties, experiment and natural pastures calculated for a dry substance.

Standing density
variety
Caravan
Travinka

$\begin{gathered}10 \text { thousand } \\ \text { plants/ha }\end{gathered}$
0.4
0.7

20 thousand
plants/ha
1.3
1.1

40 thousand
plants/ha
1.1
2.5

\begin{tabular}{|c|} 
Natural pasture \\
\hline 0.06 \\
\hline
\end{tabular}

Thus, one hectare of perennial sorghum gives 6--42 times more feed units than the degraded natural pasture.

The analysis of research data shows that the use of perennial sorghum makes it possible to feed more animals with highly nutritious food, without increasing the pasture area.

In the green mass of sorghum, the content of sugar and main macroelements was determined (Table 5).

It was found that the perennial sorghum sugar content exceeds the content of sugar in all legume grasses and legume bluegrass grass mixtures (12-30 g), corn cobs (30 g), alfalfa hay (22 g), carrots (50 g), fodder beet (53 g), pumpkin (45 g), corn (20 g), peas (35 g), lupine (35 g), etc.

The content of microelements per $1 \mathrm{~kg}$ of green mass of sorghum can cover the daily rate need for normal development of all animals.

Being an excellent winter pasture plant, perennial sorghum plays a large ameliorative role in semi-desert ecosystems, since its high stems retain snow on lowland pastures. 
TABLE 6: Content of sugar and main macronutrients in perennial sorghum.

\begin{tabular}{l|c} 
Indicators & Per $1 \mathrm{~kg}$ of green mass \\
\hline Sugar, g & 76 \\
Calcium, g & 7 \\
Phosphorus, g & 2.5 \\
Potassium, g & 19
\end{tabular}

\section{Results and Discussion}

According to the research results, the following conclusions were drawn:

- perennial sorghum is a plant which unpretentious to soil conditions, capable of growing on low-humus (0.63--0.75 \%) alkaline soils;

- even in extremely stressful weather conditions (absence of precipitation and productive moisture in the soil, high daytime temperatures and relative air humidity below $30 \%$ ), all the phases of sorghum vegetation were normal, without stopping and going into anabiosis;

- the green mass yield was 18 times higher than that of the natural pasture; the dry mass yield was 26 times higher than that of the natural pasture;

- $1 \mathrm{~kg}$ of dry mass has a nutritional value 1.5 times higher in comparison with the grass cover of natural degraded pastures;

- 1 ha of sorghum forage land can produce 0.4--2.5 tons of fodder units, which is 6--42 times more than the natural pasture can produce;

- by the content of sugar and main macro-elements, sorghum exceeds most of the grasses, and its inclusion in the diet of all animal species will cover the daily rate required for their normal development.

\section{Conclusion}

In climatic conditions of semi-deserts, sorghum is able to grow even under stressful conditions (soil and atmospheric drought).

In comparison with the natural vegetation of pastures, sorghum has a great potential for increasing the nutritional value of arid lands.

The use of sorghum for restoration of degraded pastures in the arid zone of southern Russia will contribute to the ecological restoration of lost biodiversity and productivity of semi-desert pastures. 


\section{References}

[1] Tyutyuma, N.V., Bulakhtina, G.K., Kudryashova, N.I. (2016). Introduced wildgrowing forage plants in enriching the Volga region's pasture ecosystems. News of Nizhnevolzhsk Agro-University Complex, science and higher professional education, no. 3(43), pp. 60--65.

[2] Radochinskaya, L.P., Kladiev, A.K., Rybashlykova, L.P. (2019). Production potential of restored pastures of the North-Western Pre-Caspian Sea. Arid ecosystems, vol. 25, no. 1(78), pp. 61--68. DOI: 10.24411/1993-3916-2019-10045

[3] Jacobs, I.S., Bean, C.P. (1963). Fine particles, thin films and exchange anisotropy, in Magnetism, vol. III. New York: Academic, pp. 271--350.

[4] Tserenpurev, B.-O., Masato, Sh., Yunxiang, Ch., Yadamjav, P. (2016). Effects of grazing and precipitation variabilityon vegetation dynamics in a Mongolian dry steppe. Journal of PlantEcology, no. 9(5), pp. 508--519.

[5] Dec, D., Dórner, J., Balocchi, O., López, I. (2012). Temporal dynamics of hydraulic and mechanical properties of an Andosol under grazing. Soil \& Tillage Research, no. 125 , pp. 44--51.

[6] Shamsutdinov, Z.Sh., Shamsutdinov, N.Z. (2010). The theory of N.T. Nechaeva about desert pastures. Arid ecosystems, vol. 16, no. 42, pp. 11--29.

[7] Rozentsvet, O.A., Bogdanova, E.S., Nesterov, V.N. (2016). Adaptation and Resource Potential of Plants of Arid Ecosystems, Proceedings of the Institute of Geology, Dagestan Scientific Center, Russian Academy of Sciences, iss. 67. Makhachkala: Institute of Geology, DSC of RAS, "ALEF", pp. 346.

[8] Shabala, S., Bose, J., Hedrich, R. (2014). Salt bladders: do they matter? Trends Plant Science, vol. 19, pp. 687-- 691.

[9] Kizinek, S.V., Belousov, V.S., Taranenko, V.V., Sharafullin, R.S., Volodin, A.B. (2018). Biomelioration of saline soils using sorghum crops in Western Ciscaucasia. Growing, no. 1(38), pp. 57--60.

[10] Pospelova, L.S., Pospelov, A.P., Komarov, N.M. (2009). Perennial sorghum: biology, selection, agricultural technology. Stavropol: AGRUS, 96 p.

[11] Yakushevskiy, E.S., Varadinov, S.G., Korneychuk, V.A., Banyai, L. (1982). The wide unified classifier of the CMEA and the international classifier of the CMEA of cultivated species of the genus Sorghum moench. Leningrad: All-Union Institute of Crop them Vavilova, pp. 34.

[12] Gibbens, R.P., McNeely, R.P., Havstad, K.M., Beck, R.F., Nolan, B. (2005). Vegetation changes in the Jornada Basin from 1858 to 1998. J. Arid Environ, pp. 651--668. 